\title{
Endovascular Treatment of Cerebral Aneurysms: Technical Options in Coil Embolization
}

뇌동맥류의 혈관 내 치료: 코일색전술의 기술적 선택

Moon Hee Han, MD*

Department of Neurosurgery, VHS Medical Center, Seoul, Korea

Since the endosaccular coil embolization technique was introduced as an alternative for treating selected patients with aneurysms, it has become a mainstay of treatment for cerebral aneurysms. In lesions with a neck larger than the aneurysmal body, an irregular shape, or arterial branches incorporated within the sac, endovascular treatment using detachable coils are traditionally contraindicated because of technical difficulties. Coil embolization has evolved as a result of both the development of related devices and the introduction of technical improvements using various devices. Use of various technical and device options can make endovascular treatment of cerebral aneurysms safer and can widen the treatment indications. Various technical options, including the technical modification of device-assisted techniques, will be presented, and the related practical points will be discussed in this issue.

Index terms Brain; Aneurysm; Therapeutic Embolization

서론

분리형 코일(detachable coil)을 이용한 뇌동맥류의 혈관 내 치료기법이 고안되어 임상적 용이 처음 보고된 이후(1), 이 방법을 이용한 뇌동맥류의 치료는 획기적으로 발전하여, 뇌동 맥류 치료에 있어 수술적 방법과 함께 기본적인 방법의 하나가 되었으며, 최근 우리나라에서 도 수술적 방법을 능가하는 빈도의 임상적용으로 뇌동맥류의 주된 치료 방법으로 발전하게 되었다(2). 임상적용의 확대는, 기존에 적용의 기술적 제한점으로 생각되었던 부분에 대한 치 료기법의 발전에 기인한 바가 크다. 특히 동맥류 입구의 상대적인 크기가 치료의 대상을 제 한하는 매우 중요한 기술적 요소였는데, 이런 제한점을 극복하는 여러 방법이 고안되었고, 그중에서 여러 기구를 보조적으로 함께 사용하는 여러 기법이 개발되어 사용되고 있다.
Received December 21, 2019

Revised March 16, 2020 Accepted April 2, 2020

*Corresponding author Moon Hee Han, MD Department of Neurosurgery, VHS Medical Center, 53 Jinhwangdo-ro 61-gil, Gangdong-gu, Seoul 05368, Korea.

Tel 82-2-2225-3900

E-mail hanmoonhee@gmail.com

This is an Open Access article distributed under the terms of the Creative Commons Attribution Non-Commercial License (https://creativecommons.org/ licenses/by-nc/4.0) which permits unrestricted non-commercial use, distribution, and reproduction in any medium, provided the original work is properly cited.

\section{ORCID ID}

Moon Hee Han (D) https:// orcid.org/0000-0001-5476-3482 
이 방법들은 치료의 과정에서 동맥류 내에 삽입되는 코일의 일부가 모동맥(parent artery)으로 빠 져나오는 것을 방지하는 기법들이며, 기술적 난이도와 시술에 따른 위험도는 각 기법에 따라, 또한 병변과 주변 혈관의 양상에 따라 서로 다르다. 따라서 동맥류와 주변 혈관의 상황에 따라 적절한 기법을 선택할 필요가 있으며, 원칙적으로 위험도가 가장 낮은 기법을 먼저 선택하여 시도하는 것 인 바람직하다.

코일색전술에 의한 고식적 낭내 폐색(endosaccular occlusion)의 기법으로 치료가 어려운 거 대 동맥류 혹은 방추형 동맥류의 치료를 위하여 혈류분산 스텐트(flow diverter stent)를 시용하는 새로운 개념의 치료가 임상에 적용되어 사용되고 있는데, 특수한 상황에서의 제한적인 적용으로 좋은 결과를 보이고 있다(3). 그 외에 여러 가지 실험적인 새로운 개념의 기구가 개발되어 임상적 용이 시도되고 있으나(4), 본 기고에서는 일반적인 낭성(saccular) 뇌동맥류에 있어서 혈관 내 치 료의 기본적 기법인 낭내 코일색전술에서, 동맥류의 모양에 의한 기술적 제한점을 극복하는 여러 가지 보조적인 기법과 그 기술적 응용 및 주의점에 대하여 검토하고자 한다.

\section{보조적인 미세도관(Microcatheter)의 사용}

뇌동맥류에 코일을 삽입할 때 여러 개의 미세도관을 사용하는 방법을 응용하여, 모동맥(parent artery) 혹은 뇌동맥류에서 분지하는 동맥의 보호를 위해 별도의 미세도관을 사용하는 기법을 광 경 동맥류(wide-necked aneurysm)의 치료에서 유용하게 사용할 수 있다(5-7). 보조적으로 사용 되는 기구가 크기가 작고 부드러운 미세도관에 불과하므로, 그에 따르는 기술적 문제 혹은 위험도 가 가장 낮은 방법이라 할 수 있다. 보조적 미세도관의 사용에 몇 가지의 기술적 선택이 있는데 다 음과 같다.

1) 첫 코일로 안정적인 코일의 틀(frame)이 만들어지지 않았다면, 첫 코일을 분리하지 않고 또 다 른 미세도관을 같은 위치에 넣어 다음 코일을 넣어 틀을 안정시키는 방법이며, 가장 흔히 선택할 수 있고 잘 알려진 매우 간단한 기법이다. 한 혈관 내에 두 개의 미세도관을 사용하게 되므로 시술에 관련된 혈전색전증(thromboembolism)의 위험을 이론적으로 높일 수는 있으나 모동맥의 혈류가 유지되는 상태이므로 실제로는 그 위험도가 그리 높지 않아 보조적인 기법으로는 가장 안전하며 효과적인 방법이다. 가능하면 다른 종류의 미세도관을 사용하여 시술 중 투시에서 두 기구를 구별 할 수 있게 하는 것이 중요하며, 말단부 모양이 다른 미세도관들을 사용하면 동맥류 내에 약간 다른 위치에 코일이 삽입될 수 있어 안정적인 코일의 틀을 만드는데 효과적이며 기술적으로 유리하다.

2) 크기가 크거나 모양이 불규칙한 동맥류의 치료에서는 많은 경우에서 치료된 동맥류의 각 부분 이 균일하지 않은 코일의 치밀도를 보이게 되는데, 이를 방지하기 위한 방법으로도 복수의 미세도 관을 사용할 수도 있다. 동맥류 내 서로 다른 위치에 복수의 미세도관을 위치시키고 이들 미세도관 을 통하여 코일을 삽입하면 상대적으로 균일하게 코일을 채울 수 있으며, 이 방법은 하나의 동맥류 내에서 여러 부분(compartment)에 따로 삽입된 코일이 결국 하나의 덩어리를 이루게 되는 기법 이다(Fig. 1). 코일을 채우고자 하는 동맥류의 각 부분에 미세도관을 위치시킬 수 있도록 적절한 크 기와 방향으로 말단부 모양을 성형하여 사용하는 것이 안전하고 효과적인 치료를 위해 중요하다.

3) 모동맥이나 동맥류 혹은 그 주변에서 분지하는 동맥을 보호하기 위해 별도의 미세도관을 사 
Fig. 1. Compartmental coiling in a deeply bilobed unruptured aneurysm of the anterior communicating artery in a 73-year-old man.

A. An angiographic image of the left internal carotid artery in the working projection shows two compartments of the aneurysmal sac with larger, posterior and smaller, anterior compartments.

B. Compartmental coil embolization was planned, and the first microcatheter, with a twisted S-shaped terminal curve, is navigated with the tip positioned at the larger, posterior compartment.

C. The first coil is inserted, and the second microcatheter, with a reversely twisted S-shaped terminal curve, is navigated with the tip positioned at the smaller, anterior compartment.

D. Multiple coils are inserted in the sac using two microcatheters alternately, and the post-embolization angiographic image shows occlusion of the sac with preserved flow of the two anterior cerebral artery branches.

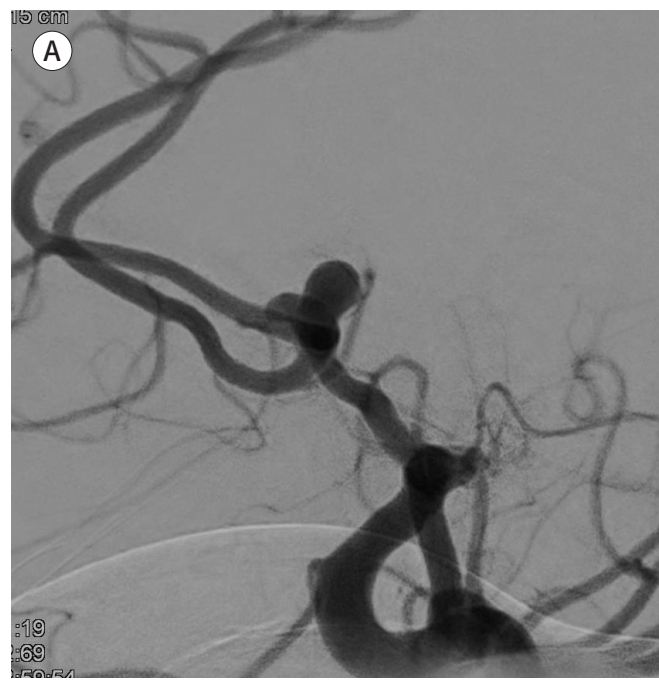

\section{(B)}
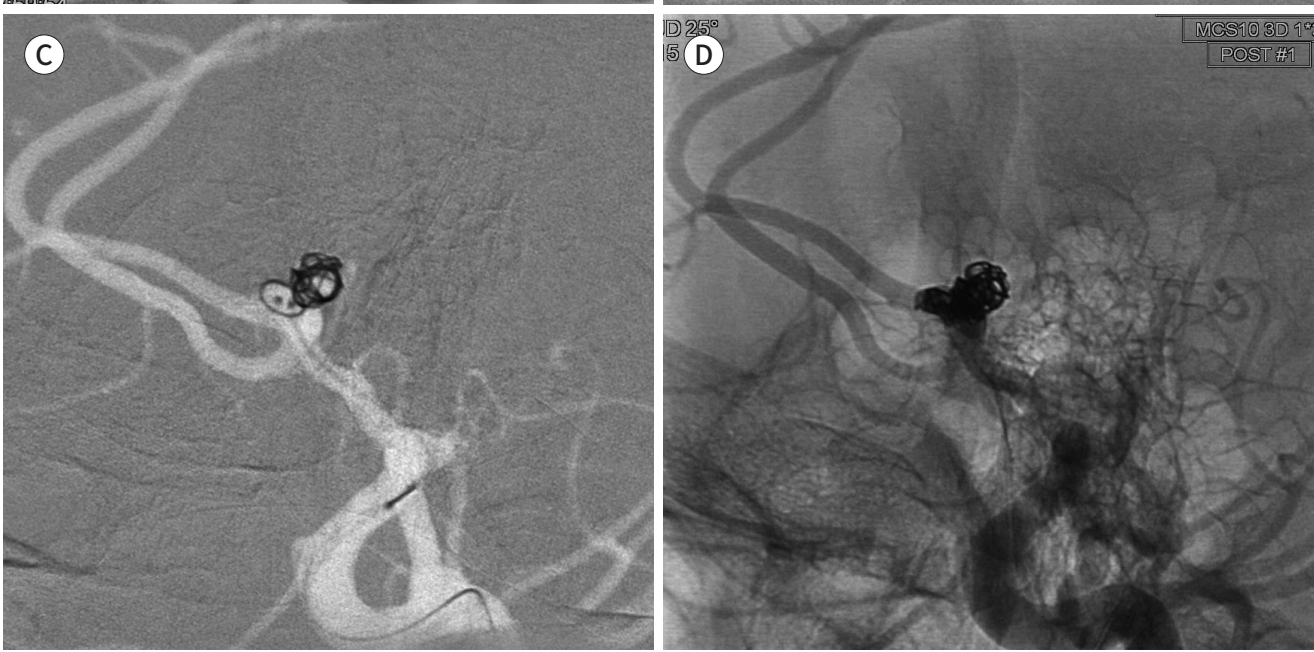

용할 수 있다(8). 동맥류 입구를 가로지르는 미세도관을 위치시켜 삽입되는 코일의 고리(loop)가 모동맥으로 빠져나오는 것을 부분적으로 막아주며 안정적인 틀을 만들 수 있다. 코일의 여러 고리 는 중첩되어 자리 잡으며 서로가 서로를 안정적으로 만들어 주므로 처음 몇 개의 고리가 나오는 것을 별도의 미세도관으로 막아주면 의외로 쉽게 안정적인 틀을 만들 수 있게 된다. 미세도관으로 동맥류 주변의 작은 분지를 선택해 놓고 동맥류를 폐색하면 미세도관 자체의 크기만큼 혈류가 유 지될 공간을 확보할 수 있게 되므로 분지의 보호에 유용하게 사용할 수 있다(Fig. 2). 기술적 목적 에 맞게 적당한 모양의 미세도관을 선택하여 정확히 위치시키는 것이 유리한데, 위치시키고자 하 
Fig. 2. The microcatheter protection technique for an anterior communicating artery aneurysm in a 70-year-old woman.

A. An angiographic image of the left internal carotid artery in the working profile projection shows an anteriorly directing aneurysmal sac, with the left anterior cerebral artery supplying both sides.

B. The first microcatheter with a J-shaped tip is positioned at the anterior communicating artery for protecting the lumen during coil insertion.

C. The first coil is inserted to form a coil frame using the second microcatheter positioned in the aneurysmal sac, and the first microcatheter is in a protective position to prevent protrusion of the coil loop.

D. Multiple coils are inserted in the sac under protection of the anterior communicating arterial lumen, and the post-embolization angiographic image shows occlusion of the sac with preserved luminal profile of the parent artery.
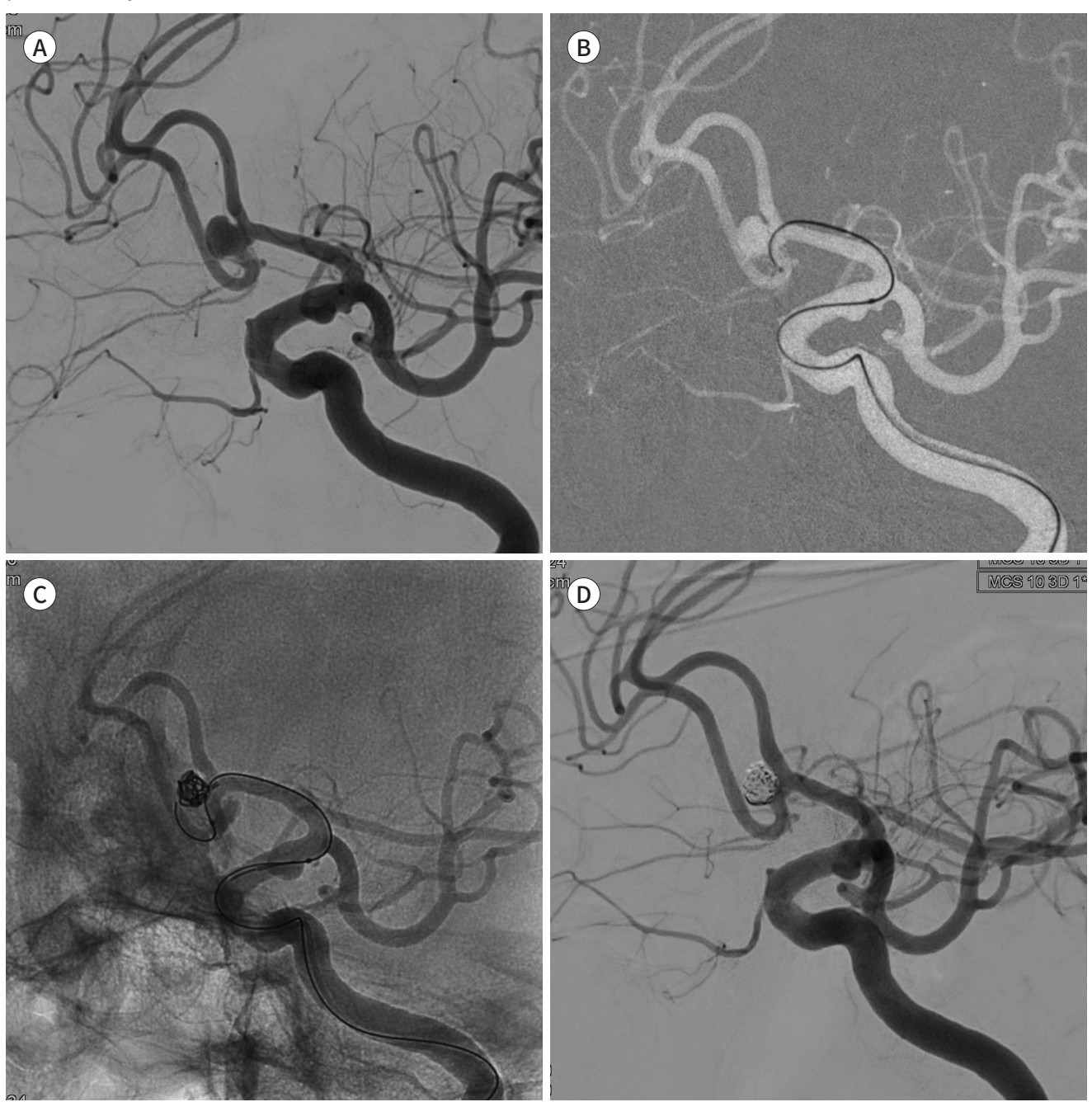

는 혈관의 크기나 방향에 따라서 도관의 단순한 전진으로 가능하지 않을 경우 미세도관의 말단부 모양을 이용하여 예각으로 기시하는 분지로 접근하는 특수한 기법을 사용하여 미세도관을 위치 시켜야 할 경우도 있다(9).

4) 분지나 모동맥의 보호를 위해 미세도관이 아닌 그 내부로 접근시킨 미세와이어 혹은 코일을 이용하는 방법도 선택할 수 있다(10-12). 와이어는 미세도관 보다는 크기가 작아 보호 효과가 상대 적으로 작을 수 있겠으나, 다양한 모양을 만들 수 있고 방향 조종이 가능하여 미세도관을 위치시 킬 수 없는 각도나 크기의 분지에서도 유용하게 사용할 수 있다. 코일은 사용되는 모든 기구 가운 
Fig. 3. Coil protection technique for an anterior communicating artery aneurysm in a 56-year-old woman. A. A three-dimensional angiographic image of the left internal carotid artery in the working profile projection shows a wide-necked aneurysm, with both anterior cerebral arteries of the second segment arising from the aneurysmal neck.

B. An angiographic image of the left internal carotid artery in the working profile projection shows no evidence of unopacified blood flow from the opposite anterior cerebral artery.

C. A coil size matched to the depth of the aneurysmal sac is inserted under the protection of the neck in front of the left anterior cerebral artery with a space occupied by a small coil (arrow).

D. After making a stable coil framework with this protection technique, multiple coils are inserted, and postembolization angiography shows complete occlusion of the aneurysmal sac with preservation of the anterior cerebral artery lumen on both sides.
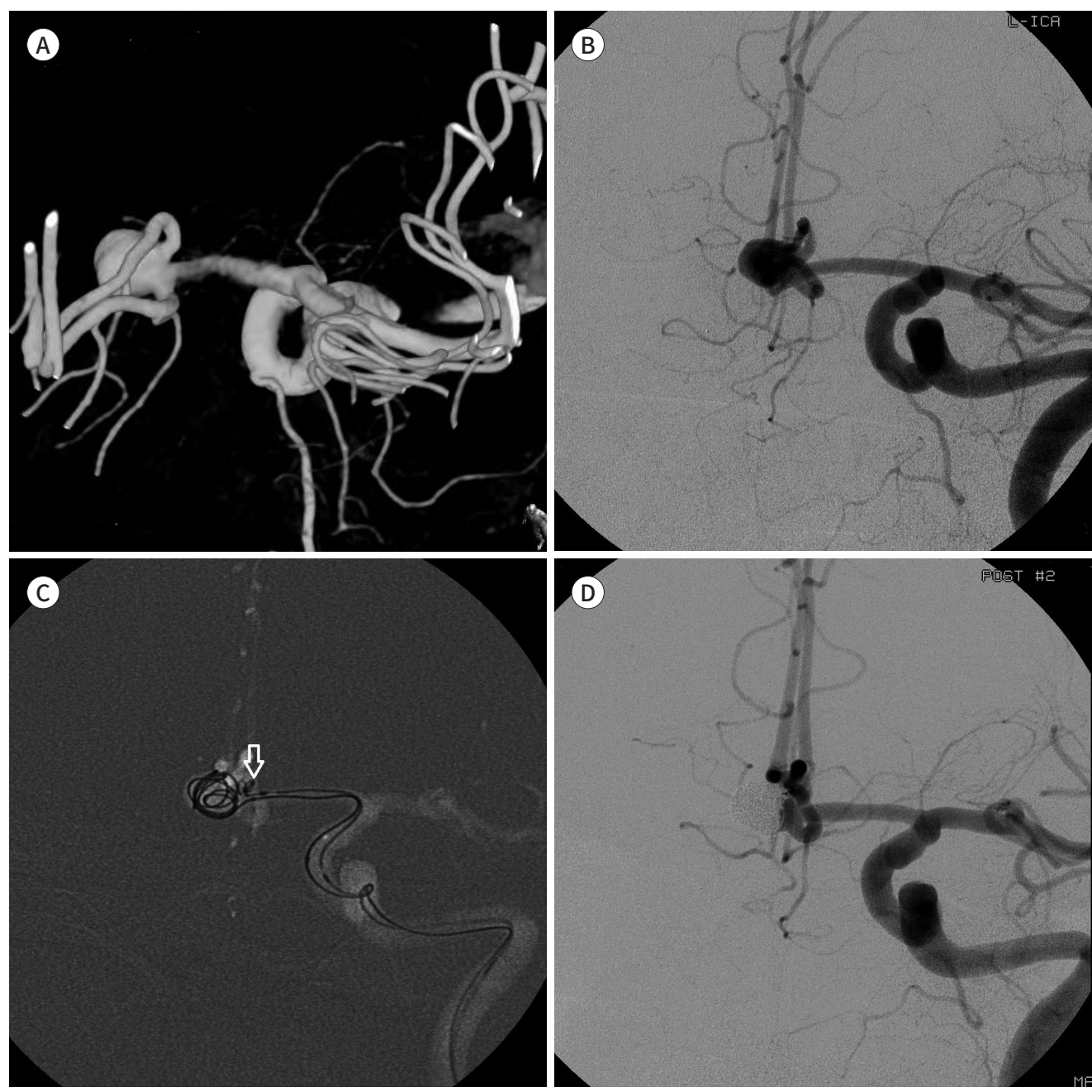

데 가장 부드러운 기구이며 다양한 크기와 모양을 선택할 수 있으므로 안전하게 사용할 수 있다. 보호해야 할 동맥류 혹은 주위의 특정 부위에 미리 작은 크기의 코일을 위치시켜 공간을 점유한 후, 동맥류에 안정적인 코일의 틀이 만들어진 후에 보호용 코일을 제거하면 그 코일이 있던 자리 의 혈류를 유지할 수 있게 된다(Fig. 3).

복수의 미세도관을 사용할 때 가능하면 하나의 유도도관(guiding catheter)을 사용하여 그 안 으로 복수의 미세도관을 넣어 사용하는 것이 좋다. 두 개의 미세도관으로 서로 다른 코일을 삽입 할 때 두 코일이 서로 엉켜 빠지지 않는 경우가 발생할 수도 있는데, 이 경우 동일한 유도도관을 사 
용한 경우에는 코일이 들어 있는 두 개의 미세도관을 함께 제거하여 문제를 안전하게 해결할 수 있기 때문이다. 치료의 기술적 계획 단계에서 사용하고자 하는 기법의 선택에 따라 사용할 기구의 수와 외경을 고려하여 적절한 내경의 유도도관을 선택하여야 한다.

\section{풍선카테터를 사용한 기법}

뇌동맥류에 삽입된 코일이 모동맥으로 탈출하는 것을 방지하는 가장 확실하고 직접적인 방법으 로 풍선보조 코일색전술(balloon-assisted coil embolization)이 있다. 이는 임시폐색용(temporary occlusion) 풍선도관을 사용하여 코일 삽입 중 풍선을 팽창시켜 모동맥의 내경을 확보하는 방법이다. 풍선이 팽창되어 모동맥을 보호하는 동안 미세도관을 한 방향으로 밀어 고정하게 되고 이렇게 고정된 미세도관으로 삽입되는 코일이 동맥류 벽에 손상을 줄 수 있으며, 기구의 외경이 상대적으로 크고, 풍선의 팽창으로 혈류를 일시적으로 차단하는 기법이므로 시술의 이론적인 위 험도가 상대적으로 높은 방법이다(13). 따라서 매우 유연한 재질의 풍선을 사용하며 가급적 파열 된 동맥류에서는 사용하지 않는 것이 좋다.

동맥류의 근위부 혹은 원위부에서 풍선을 팽창시킬 수 있으므로 풍선의 위치에 따라 모동맥의 보호에 있어 다른 역할을 하게 되며, 풍선의 팽창 정도를 조절하며 다른 보호 효과를 기대할 수도 있어 다양한 기법을 사용할 수 있다. 풍선을 팽창시킬 때 모동맥의 혈류에 의하여 항상 기구가 원 위부로 밀리게 되고, 반대로 수축시킬 때는 근위부로 다시 이동하는 현상이 나타나는 점을 염두에 두고 풍선도관을 조종하여야 하는데, 도관 내에 와이어를 넣어 사용하면 이러한 불안정성을 부분 적으로 방지할 수 있다.

풍선도관과 미세도관의 상대적인 위치에 따라 풍선에 의해 밀려 미세도관의 방향과 위치가 변 하게 되는데, 도관 말단부의 위치와 방향에 따라 삽입되는 코일의 양상이 달라질 수 있으므로 두 기구의 상대적인 위치를 미리 고려하여야 한다. 두 기구의 상대적인 위치는 기구의 삽입 순서에 의해 결정되는데, 그 순서를 변경하여 풍선도관의 상대적인 위치를 바꿀 수도 있다. 미세도관이 먼저 위치하여 상대적인 위치가 만들어졌으나 치료의 과정에서 그 상대적인 위치를 바꿀 필요가 있는 경우, 먼저 들어간 미세도관을 내렸다가 다시 위치시키면 두 기구가 들어간 순서가 서로 바 뀌게 되므로 상대적인 위치도 바뀔 수 있다. 이처럼 시술 과정에서 풍선의 팽창에 의한 미세도관 의 위치 변화 양상을 판단하여 미세도관의 위치 변경이 필요하다고 판단되는 경우, 이 기법을 이 용하여 기술적으로 유리한 상황을 만들 수 있다(Fig. 4).

\section{스텐트를 보조적으로 사용하는 기법}

동맥류 주변의 모동맥 혹은 분지혈관을 따라 설치한 스텐트로 주변 혈관의 내경을 보호하는 기 법으로 미세도관을 통하여 삽입, 설치하는 자가팽창형 스텐트가 주로 사용된다. 적절한 모양의 미 세도관으로 동맥류를 선택한 후 그 위로 스텐트를 설치하는 방법과, 먼저 스텐트를 설치한 후 그 지주(strut) 사이로 미세도관을 동맥류로 넣어 코일을 삽입하는 방법이 있다. 또한 일반적인 시술 의 과정에서 코일의 고리가 모동맥으로 돌출한 경우 그로 인한 모동맥이나 분지의 혈류 방해를 방 지할 목적으로 사용되기도 한다. 일반적으로 스텐트의 설치에 의하여 혈관의 각도가 변하게 되고 
Fig. 4. Balloon-assisted embolization of a right internal carotid artery aneurysm in a 62-year-old woman. A. An angiographic image of the right internal carotid artery in the working profile projection shows an aneurysm, with a neck wider than the depth, at the bifurcation of the internal carotid artery.

B. A shaped-tip microcatheter is positioned in the sac, and an occlusion balloon catheter is positioned at the bifurcation of the internal carotid artery to protect the parent artery. The fluoroscopic view in the lateral projection during the second coil insertion shows the microcatheter positioned relatively anterior to the inflated balloon.

C. For coiling to close the posterior part of the sac, the microcatheter is withdrawn and repositioned to switch the relative position of the two devices. The fluoroscopic view in the lateral projection during the last coil insertion shows the microcatheter positioned relatively posterior to the inflated balloon.

D. An angiographic image in the profile projection after embolization shows complete occlusion of the aneurysmal sac with preservation of the parent artery and branches.
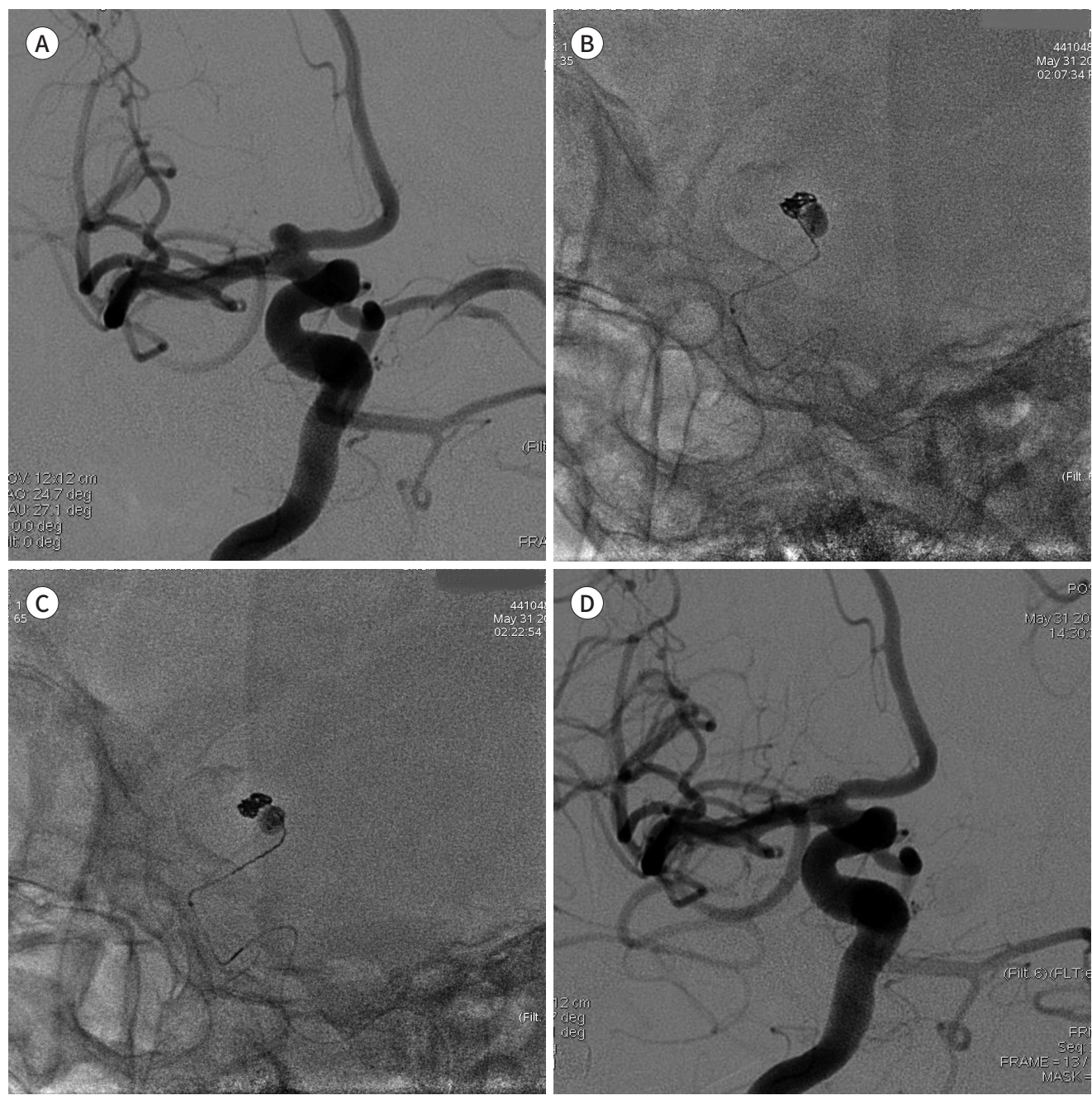

혈류의 변화가 초래되어 동맥류 치료 효과에 영향이 있는데, 대체로 장기적인 폐색 효과를 증가시 키는 것으로 알려져 있다(14-16).

금속성 기구가 영구적으로 설치되고, 스텐트에 의한 내막의 자극으로 인한 혈소판 응집과 혈전 형성의 위험이 있어 일반적으로 항혈소판제제의 투여에 의한 전처치를 한 후에 시술하는 것이 원 칙이며, 파열된 동맥류에서는 이러한 준비를 할 수 없으므로 스텐트 설치 직후 항혈소판제제를 투 여하여야 한다(17). 현재 이러한 목적으로 개발되어 상용화된 스텐트는 Neuroform ${ }^{\circledR}$ (Stryker, 
Kalamazoo, MI, USA), Enterprise ${ }^{\circledR}$ (Johnson \& Johnson Codman, Miami, FL, USA), 그리고 LVIS $^{\circledR}$ (MicroVention, Aliso Viejo, CA, USA) 등이 있는데, 서로 다른 형태와 구조를 가지므로 기 구의 특징과 혈관의 상황에 맞게 선택하여 사용해야 하며, 혈관의 구조에 따라 설치하는 위치를 달리하여 다른 보호 효과를 기대할 수 있다.

스텐트를 설치하는 경로와 위치에 따라 다양한 기술적 응용의 선택이 있는데 1) 순방향(antegrade) 혹은 역방향(retrograde)의 접근, 2) 동측(ipsilateral) 혹은 반대측(contralateral)으로부터 의 접근, 3) 종단(longitudinal) 혹은 횡단(horizontal) 방향의 설치, 4) 혈관의 전체(full coverage) 혹은 부분(partial coverage)을 포함하는 설치 등이 있다. 병변의 위치에 따른 주변 혈관의 연결, 혈관의 크기와 각도 등, 다양한 양상에 따라 적절한 기법을 선택할 수 있으며, 당연히 상황에 맞으 며 가장 위험도가 낮은 기법을 선택하여야 한다.

1) 혈류의 역방향 접근에 의한 스텐트의 설치는 후순환과 연결이 있는 후교통동맥(posterior communicating artery)의 동맥류에서 선택할 수 있다(18). 대체로 내경동맥에서 예각으로 기시 하는 후교통동맥의 각도 때문에 순방향으로 접근하여 스텐트를 설치하는 것보다 역방향으로 후 대뇌동맥(posterior cerebral artery)을 통하여 접근하여 후교통동맥과 원위부 속목동맥(internal carotid artery)에 걸쳐 스텐트를 설치하면 자연스러운 각도의 스텐트 위치로 동맥류의 치료가 쉬 워진다(Fig. 5). 이때 코일을 삽입하는 미세도관은 순방향으로 동맥류로 접근하여 치료하게 되므 로 경우에 따라 양측 넙다리동맥(femoral artery)을 이용하여 두 개의 유도도관을 내경동맥과 척 추동맥에 따로 위치시킬 필요가 있는 경우도 있다. 이러한 기법은 혈관이 모동맥의 혈류 방향에서 예각으로 분지하는 후하소뇌동맥(posterior inferior cerebellar artery)의 동맥류에서도 적용되 는데 반대측 추골동맥으로 접근하여 원위부 척추동맥의 혈류를 거슬러 내려오며 후하소뇌동맥에 스텐트를 설치하고 동맥류의 코일색전술은 순방향의 접근으로 시행하는 개념이다(19). 이는 다음 에 언급되는 반대측 접근법과 유사한 기술적 개념이다(Fig. 6).

2) 반대측 접근에 의한 스텐트 설치의 기법은 중앙의 연결통로가 있는 경우에 선택할 수 있는 기 법이다. 전교통동맥(anterior communicating artery)의 광경동맥류에서 모동맥의 보존을 위하 여 동맥류에서 반대측 접근에 의하여 스텐트를 설치하고 동측을 통하여 코일 삽입을 할 수 있다. 반대측을 통한 접근은 스텐트의 설치뿐만 아니라 단순 코일색전술에서도 적용할 수 있는데, 동측 접근에 의한 방법이 혈관의 구조와 크기에 의하여 기술적으로 어려운 경우이며 전대뇌동맥(anterior cerebral artery) 근위부 동맥류에서 사용할 수 있는 기술적 선택이다(20).

3) 횡단스텐트 설치에 의한 치료는 주로 기저동맥 분지부의 광경 동맥류에서 양측 후대뇌동맥 (posterior cerebral artery)에 대칭으로 위치하는 광경 동맥류에서 적용할 수 있는 방법이다. 후교 통동맥을 통한 접근이 가능한 경우에 선택할 수 있으며, 후교통동맥-동측 후대뇌동맥-기저동맥 분 지부 반대측 후대뇌동맥의 경로로 접근하여 스텐트를 설치하게 된다. 코일의 삽입은 기저동맥을 통한 일반적인 접근으로 가능하며 이 경우 스텐트에 의해 보호되는 기저동맥 분지부의 횡단영상의 각도를 적절히 설정하여 시술을 할 필요가 있다. 양측 후대뇌동맥의 보호가 필요한 광경동맥류이나 횡단 스텐트 설치를 위한 접근 경로가 없는 경우에는 두 개의 스텐트를 사용하여 양측 후대뇌동맥 을 따로 보호하는 기법을 사용할 수도 있다(21). 이처럼 동맥류 양측의 혈관을 보호할 목적으로 복 
Fig. 5. Retrograde stenting from the distal internal carotid artery to the posterior communicating artery for assisting coil embolization of a right posterior communicating artery aneurysm in a 65-year-old man.

A. A three-dimensional angiographic image of the right internal carotid artery in the working profile projection shows a large and wide-necked aneurysm, with acute arising angle of the posterior communicating artery from the internal carotid artery.

B. Through the vertebral and basilar arterial route, right posterior communicating artery is catheterized with a stent-delivery microcatheter, and the fluoroscopic image shows the stent-loaded microcatheter positioned at the distal internal cerebral artery crossing the lesion.

C. The aneurysmal sac is catheterized with the antegrade approach through the right internal carotid artery, and the first coil is deployed for making a frame.

D. After making a stable coil framework with the stent-assisted technique, multiple coils are inserted, and post-embolization angiography shows complete occlusion of the aneurysmal sac with preservation of the posterior communicating and internal carotid arteries.
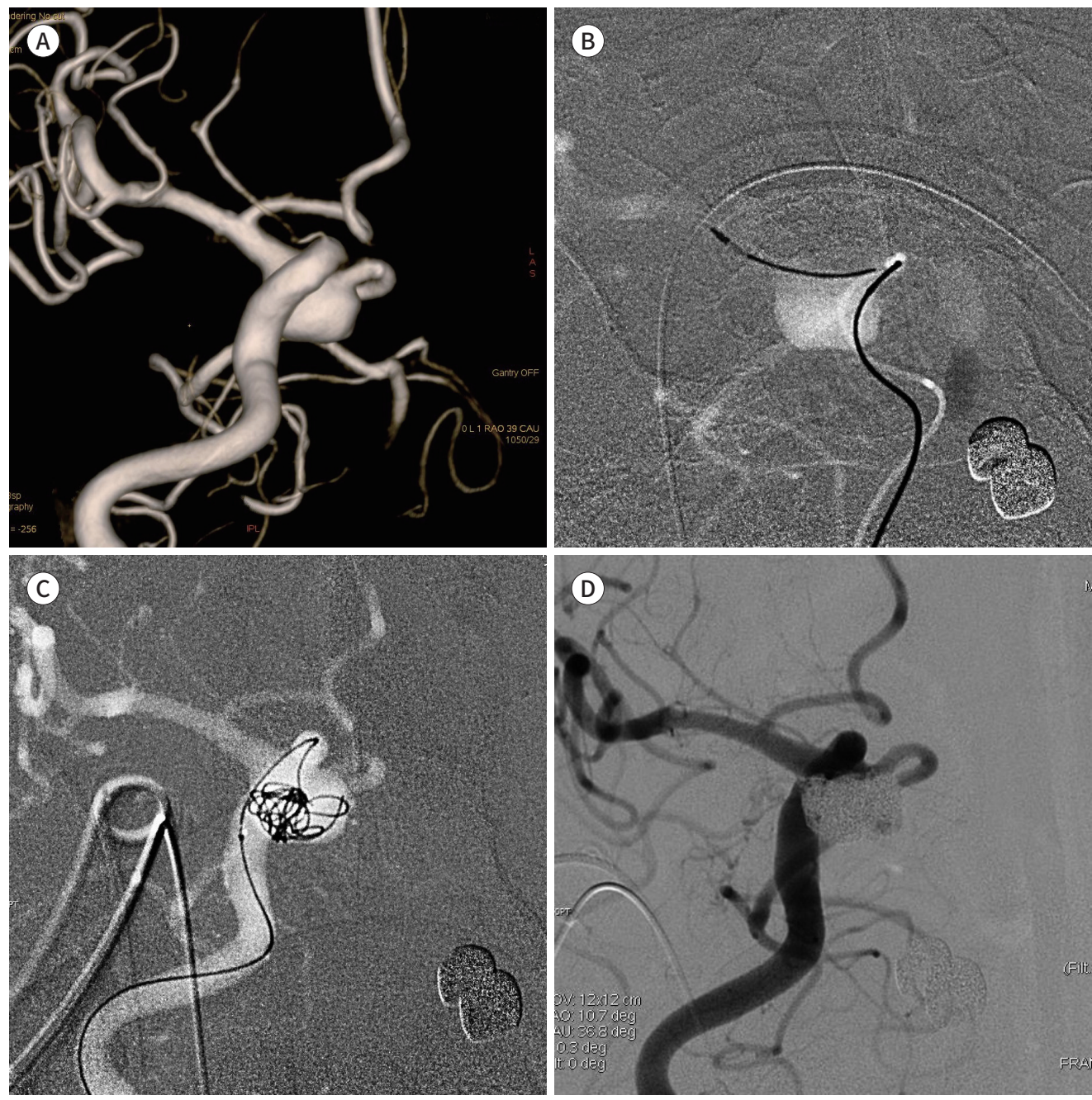

수의 스텐트를 사용해야 할 경우, 중복된 스텐트 부분에 의하여 이론적으로 증가하는 혈전색전증의

위험성을 피하기 위하여 가능하면 스텐트가 중복 설치되지 않는 기법을 선택할 필요가 있다.

4) 동맥류와 모동맥의 부분을 포함하는 스텐트의 설치를 고려할 수도 있다(22). 동맥류의 위치와 주변 혈관의 각도로 인하여 모동맥과 동맥류를 모두 포함하기가 부자연스럽거나, 예각으로 설치 되거나, 두 개 이상의 굴곡이 포함되어 스텐트의 불완전한 팽창이 우려되는 경우 등에서 선택할 수 있는 기법이다. 동맥류의 원위부 혈관에서 시작하여 동맥류 입구 근처에 스텐트 근위부 말단이 
Fig. 6. Contralateral vertebral artery approach for stenting the left posterior inferior cerebellar artery in a 67-year-old woman.

A. An angiographic image of the left vertebral artery in the working profile projection shows an aneurysm at the posterior inferior cerebellar artery, with an acute arising angle of the arterial origin from the left vertebral artery.

B. Through the opposite side of the vertebral artery route, the left posterior inferior cerebellar artery is catheterized for stenting, and another microcatheter is positioned in the aneurysmal sac for coiling with an ipsilateral approach.

C. Multiple coils are inserted subsequently, and post-embolization angiography shows complete occlusion of the aneurysmal sac with preservation of the parent arterial lumen.

D. An unsubtracted angiographic image with the same projection shows the position of the stent from the distal vertebral artery to the posterior inferior cerebellar artery covering the aneurysmal neck.
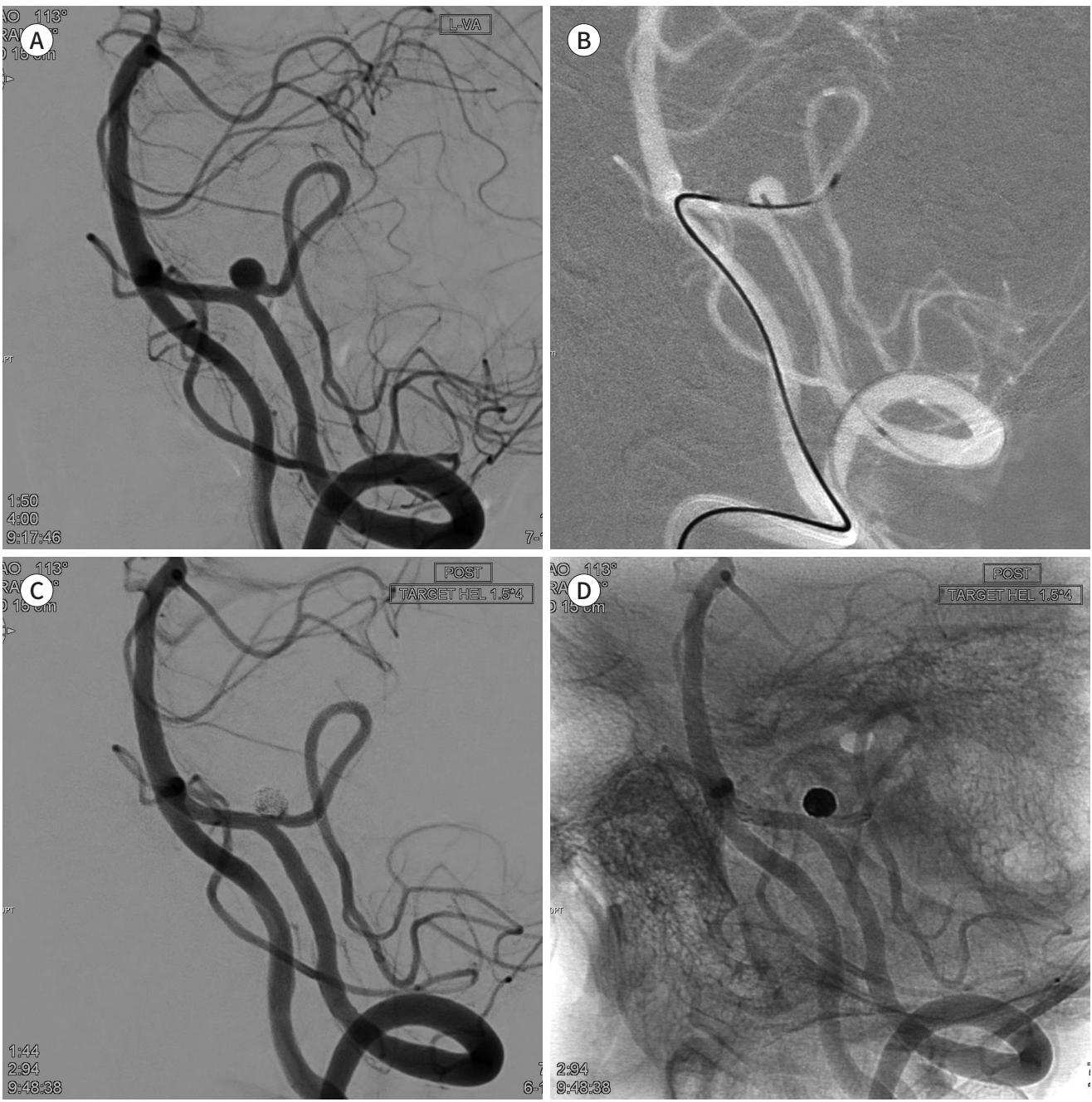

위치하도록 하는 방법으로, 동맥류 입구를 스텐트로 완전하게 포함하지 못하는 단점은 있으나, 스 텐트의 위치와 모양을 더 자연스럽게 하여 굴곡에 의한 문제를 방지할 수 있는 장점이 있어 여러 위치의 동맥류에서 유용하게 선택할 수 있는 방법이다.

\section{안전한 치료를 위한 일반적 기법과 준비}

안전하고 효과적인 코일색전술의 여러 기술적 선택에서 기구의 효율적인 조종을 위해 공통적으 
로 중요한 기법상의 원칙은 미세도관의 접근 방향과 말단부의 위치 선정이다. 미세도관의 말단부 모양을 이상적으로 성형하여, 미세도관을 전진시키면 말단부가 자연스럽게 동맥류의 중심부로 들 어가고, 미세도관을 당기면 동맥류 입구를 통하여 모동맥으로 나오게 되는 상태를 만드는 것이 가 장 이상적이다. 이러한 이상적인 미세도관 말단부의 모양을 갖게 되면 치료의 과정에서 삽입되는 코일의 형태를 의도대로 만들고 조정하며, 의도한 대로 틀을 만들고 그 내부를 치밀하게 코일로 채울 수 있어, 치료의 과정이 빠르고, 순조롭게 되며 장기적으로 좋은 결과를 기대할 수 있다(23). 이러한 미세도관 말단부의 성형(microcatheter tip shaping)은 안전한 치료를 위해서도 매우 중 요한 요소인데, 치료의 과정에서 발생할 수 있는 출혈의 상황에서도 가장 빠르게 파열부위를 효과 적으로 폐색하여 출혈을 최소화할 수 있는 기법이기도 하기 때문이다. 이를 위하여 시술 전에 병 변과 주변 혈관, 특히 근위부 모동맥의 굴곡을 삼차원적으로 세밀히 검토하는 것이 동맥류의 입구 로 접근하는 이상적인 방향을 미리 설정하여 상황에 맞는 적절한 모양으로 미세도관을 성형하는 데 중요하다.

여러 가지 보조적인 기법을 사용하는 경우 단순 코일색전술보다 이론적으로 높은 혈전색전증이 우려된다. 비파열성 동맥류의 경우 미리 항혈소판제제를 투여하면 이러한 시술상의 합병증을 최 소화할 수 있으며(24-26), 뇌졸중의 치료와는 다른 단순화한 약재의 선택으로 적용이 가능하다. 코 일색전술 중 발생하는 동맥류 주변의 혈전형성은 대부분 초기의 혈소판 응집에 의한 혈전이므로 혈전이 있는 부위에 항혈소판제의 국소 주입으로 효과적으로 해결할 수 있으며, 시술 중 발생할 수 있는 문제를 신속하게 해결하기 위해 항혈소판제를 미리 구비하는 등의 대비가 필요하다(27, 28). 이와 같이 치료 과정에서 만날 수 있는 여러 가지의 문제를 쉽고 빠르게 그리고 효과적으로 해결하기 위해서도 이상적인 말단 모양을 가진 미세도관을 준비하는 것이 기본적으로 필요하다.

\section{결론}

다양한 기법을 상황에 맞게 선택적으로 이용하는 것이 안전하고 효과적인 동맥류의 혈관 내 치 료를 위해 중요하다. 이를 위해서는 동맥류의 크기와 방향, 동맥류 각 부분의 크기, 주변 혈관의 분 지 각도와 크기, 혈관의 연결 통로 등, 병변 주변의 해부학적 양상을 삼차원적으로 미리 분석하여 적절한 기법을 선택해야 하며, 사용하고자 하는 기구들의 제원과 구조적 특성을 잘 파악하여 가장 안전한 기법을 우선 선택하여야 한다.

\section{Conflicts of Interest}

The author has no potential conflicts of interest to disclose.

\section{REFERENCES}

1. Guglielmi G, Viñuela F, Dion J, Duckwiler G. Electrothrombosis of saccular aneurysms via endovascular approach. Part 2: preliminary clinical experience. J Neurosurg 1991;75:8-14

2. Chang HW, Shin SH, Suh SH, Kim BS, Rho MH. Cost-effectiveness analysis of coiling versus neurosurgical clipping for intracranial aneurysms in Republic of Korea. Neurointervention 2016;11:86-91

3. Dmytriw AA, Phan K, Moore JM, Pereira VM, Krings T, Thomas AJ. On flow diversion: the changing landscape 
of intracerebral aneurysm management. AJNR Am J Neuroradiol 2019;40:591-600

4. Jia ZY, Shi HB, Miyachi S, Hwang SM, Sheen JJ, Song YS, et al. Development of new endovascular devices for aneurysm treatment. J Stroke 2018;20:46-56

5. Kwon OK, Kim SH, Kwon BJ, Kang HS, Kim JH, Oh CW, et al. Endovascular treatment of wide-necked aneurysms by using two microcatheters: techniques and outcomes in 25 patients. AJNR Am J Neuroradiol 2005;26:894-900

6. Cho YD, Rhim JK, Kang HS, Park JJ, Jeon JP, Kim JE, et al. Use of triple microcatheters for endovascular treatment of wide-necked intracranial aneurysms: a single center experience. Korean J Radiol 2015;16:1109-1118

7. Kwon OK, Kim SH, Oh CW, Han MH, Kang HS, Kwon BJ, et al. Embolization of wide-necked aneurysms with using three or more microcatheters. Acta Neurochir (Wien) 2006;148:1139-1145

8. Lee JY, Seo JH, Cho YD, Kang HS, Han MH. Endovascular treatment of wide-neck intracranial aneurysms using a microcatheter protective technique: results and outcomes in 75 aneurysms. AJNR Am J Neuroradiol 2011;32:917-922

9. Cho YD, Kang HS, Kim JE, Son YJ, Lee JY, Lee SJ, et al. Microcatheter looping technique for coil embolization of complex configuration middle cerebral artery aneurysms. Neurosurgery 2012;71:1185-1191

10. Cho YD, Kang HS, Kim JE, Ahn JH, Jung SC, Kim CH, et al. Microguidewire protection of wide-necked aneurysms incorporating orifices of tortuous acute-angled vessels: a novel approach. Neuroradiology 2014;56: 553-559

11. Cho YD, Lee JY, Seo JH, Lee SJ, Kang HS, Kim JE, et al. Coil protection using small helical coils for wide-neck intracranial aneurysms: a novel approach. AJNR Am J Neuroradiol 2013;34:164-168

12. Cho YD, Rhim JK, Park JJ, Jeon JP, Kang HS, Kim JE, et al. Modified coil protection for proper coil frame configuration in wide-necked aneurysms. Neuroradiology 2015;57:705-711

13. Layton KF, Cloft HJ, Gray LA, Lewis DA, Kallmes DF. Balloon-assisted coiling of intracranial aneurysms: evaluation of local thrombus formation and symptomatic thromboembolic complications. AJNR Am J Neuroradiol 2007;28:1172-1175

14. Cho WS, Kang HS, Kim JE, Kwon OK, Oh CW, Cho YD, et al. Angle change of the parent arteries after stent-assisted coil embolization of wide-necked intracranial bifurcation aneurysms. Clin Radiol 2014;69:e63-70

15. Cho WS, Hong HS, Kang HS, Kim JE, Cho YD, Kwon OK, et al. Stability of cerebral aneurysms after stent-assisted coil embolization: a propensity score-matched analysis. Neurosurgery 2015;77:208-216; discussion 216-217

16. Jeon JP, Cho YD, Rhim JK, Park JJ, Cho WS, Kang HS, et al. Effect of stenting on progressive occlusion of small unruptured saccular intracranial aneurysms with residual sac immediately after coil embolization: a propensity score analysis. J Neurointerv Surg 2016;8:1025-1029

17. Choi HH, Lee JJ, Cho YD, Han MH, Cho WS, Kim JE, et al. Antiplatelet premedication for stent-assisted coil embolization of intracranial aneurysms: low dose prasugrel vs clopidogrel. Neurosurgery 2018;83:981-988

18. Cho YD, Lee WJ, Kim KM, Kang HS, Kim JE, Han MH. Stent-assisted coil embolization of posterior communicating artery aneurysms. AJNR Am J Neuroradiol 2013;34:2171-2176

19. Cho YD, Kang HS, Lee WJ, Kim KM, Kim JE, Han MH. Stent-assisted coil embolization of wide-necked posterior inferior cerebellar artery aneurysms. Neuroradiology 2013;55:877-882

20. Kwon HJ, Cho YD, Lim JW, Koh HS, Yoo DH, Kang HS, et al. Contralateral approach to coil embolization of proximal Al aneurysms using the anterior communicating artery. AJNR Am J Neuroradiol 2018;39:2297-2300

21. Cho YD, Park SW, Lee JY, Seo JH, Kang HS, Kim JE, et al. Nonoverlapping Y-configuration stenting technique with dual closed-cell stents in wide-neck basilar tip aneurysms. Neurosurgery 2012;70:244-249

22. Cho YD, Kang HS, Kim JE, Cho WS, Kwon HJ, Koh HS, et al. Modified protection using far proximal portion of self-expandable closed-cell stents for embolization of wide-necked intracranial aneurysms. Neuroradiology 2014;56:851-857

23. Kwon BJ, Im SH, Park JC, Cho YD, Kang HS, Kim JE, et al. Shaping and navigating methods of microcatheters for endovascular treatment of paraclinoid aneurysms. Neurosurgery 2010;67:34-40

24. Kang HS, Han MH, Kwon BJ, Jung C, Kim JE, Kwon OK, et al. Is clopidogrel premedication useful to reduce thromboembolic events during coil embolization for unruptured intracranial aneurysms? Neurosurgery 2010;67:1371-1376

25. Ha EJ, Cho WS, Kim JE, Cho YD, Choi HH, Kim T, et al. Prophylactic antiplatelet medication in endovascular 
treatment of intracranial aneurysms: low-dose prasugrel versus clopidogrel. AJNR Am J Neuroradiol 2016;37:2060-2065

26. Cho WS, Lee J, Ha EJ, Kim KH, Lee J, Cho YD, et al. Low-dose prasugrel vs clopidogrel-based tailored premedication for endovascular treatment of cerebral aneurysms. Neurosurgery 2019;85:E52-E59

27. Kang HS, Kwon BJ, Roh HG, Yoon SW, Chang HW, Kim JE, et al. Intra-arterial tirofiban infusion for thromboembolism during endovascular treatment of intracranial aneurysms. Neurosurgery 2008;63:230-237; discussion 237-238

28. Cho YD, Lee JY, Seo JH, Kang HS, Kim JE, Jung KH, et al. Intra-arterial tirofiban infusion for thromboembolic complication during coil embolization of ruptured intracranial aneurysms. Eur J Radiol 2012;81:2833-2838

뇌동맥류의 혈관 내 치료: 코일색전술의 기술적 선택

\section{한문희*}

뇌동맥류 치료에 있어 분리형 코일을 이용한 혈관 내 치료는 여러 기법의 발전으로 말미암아 그 임상적용 빈도가 수술적 치료의 빈도를 능가하여 뇌동맥류의 주된 치료 방법으로 자리 잡 게 되었다. 혈관 내 치료의 임상적용이 확대된 데에는 기존 코일색전술이 가진 기술적 제한 점을 극복할 수 있는 여러 치료기법들의 개발에 기인한 것인데, 특히 광경동맥류를 치료할 수 있는 여러 방법이 고안되었고, 그중에서 보조적인 기구를 함께 사용하는 여러 기법이 개 발되어 사용되고 있다. 이 방법들은 치료의 과정에서 동맥류 내에 삽입되는 코일의 일부가 모동맥으로 빠져나오는 것을 방지하는 기법들이며, 기술적 난이도와 시술에 따른 위험도는 각 기법에 따라, 또한 병변과 주변 혈관의 양상에 따라 서로 달라서 상황에 따라 적절한 기법 을 선택할 필요가 있으며, 원칙적으로 위험도가 가장 낮은 기법을 먼저 선택하여 시도하는 것인 바람직하다. 본 기고에서는 일반적인 뇌동맥류에서 혈관 내 치료의 기본적인 기법인 코 일색전술에서, 기술적 제한점을 극복하는 여러 가지 보조적인 기법과 그 기술적 응용 및 주 의점에 대하여 검토하고자 한다. 